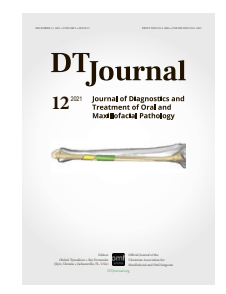

\title{
EDITORIAL
}

\section{Evolving: Becoming a Printable Digital-only Journal from January 2022}

\author{
Oleksii 0. Tymofieieva, levgen I. Fesenko ${ }^{b, *}$, \& Evangelos G. Kilipiris
}

What's dangerous is not to evolve. -Jeff Bezos

Founder of Amazon

After almost 5 years of publishing (from February 2017) of the Journal of Diagnostics and Treatment of Oral and Maxillofacial Pathology (JDTOMP) in both forms (print and digital), we are happy to announce the paradigm shift in the life of our beloved publication. The Editorial Board made the decision to move the Journal to a digital-only publication format from January 2022.

In recent years, many prestigious international peer-reviewed journals with a long history of publishing and a strong Impact Factor already made or are ferociously making such transition to digitalonly format (Table 1$) \cdot{ }^{1-4}$

Among many reasons of such transition are: (1) move to environmentally friendly format only, ${ }^{3}$ (2) spared finances in printing, subscribing, and logistics can be invested into development of media platform and technologies on its basis, ${ }^{3}$ (3) richer digital content, due to the fact that some journals do not print all pages in color, ${ }^{5}$ (4) reader engagement with print text is difficult to measure, ${ }^{1}$ (5) this

\footnotetext{
${ }^{\text {a }}$ Editor in Chief, Kyiv, Ukraine.

${ }^{\mathrm{b}}$ Managing Editor, Kyiv, Ukraine.

c Director, Journal Development Department, Bratislava, Slovak Republic.

* Corresponding author's address: OMF Publishing LLC: Journal of Diagnostics and Treatment of Oral and Maxillofacial Pathology. 13-A Simferopolska Street, Kyiv 02096, Ukraine.

E-mail: i.i.fesenko@dtjournal.org (levgen Fesenko)
}

transition reflecting the reality of how readers are using journal content in the days of internet access, ${ }^{2}$ (6) when preparing the draft of the manuscript an author rather uses internet search and downloads the multiple articles' PDF files, etc.

Such transition applies not only to medical journals. For example, such publisher as the American Institute of Aeronautics and Astronautics successfully moved all their eight journals to digitalonly format in a 2017 to 2019 period.

In our opinion, the popular term for the description of the electronic journal's format the "online-only publication" is a misnomer as it's not completely representing the potential of such publishing format of the journal. Because typically every article has a PDF file which can be printed at home, shop, or office. And in our Journal the website visitor can download both separate paper and a full issue. Thus, reader receives a possibility to work autonomously in case of lose/absence of internet connection. That is why our team proposes to use the term "printable digital journal."

And now, thanks to the team of OMF Publishing LLC our Journal has applied the evolving step similar to the journals of Oxford University Press, ${ }^{1,2,4}$ John

\footnotetext{
Please cite this article as: Tymofieiev OO, Fesenko II, Kilipiris EG. Evolving: becoming a printable digital-only journal from January 2022. J Diagn Treat Oral Maxillofac Pathol 2021;5(12):137-8.

Available online 31 December 2021

https:// doi.org/10.23999/j.dtomp.2021.12.2

C 2021 OMF Publishing, LLC. This is an open access article under the CC
} BY license (http://creativecommons.org/licenses/by-nc/4.0/). 
TABLE 1. Example of Peer-Reviewed Journals which Moved to Digital-only Format of Existence.1-4

\begin{tabular}{|c|l|c|c|c|}
\hline$\#$ & \multicolumn{1}{|c|}{ Title } & $\begin{array}{c}\text { 2020 Impact } \\
\text { Factor }\end{array}$ & $\begin{array}{c}\text { Number of Years of Print } \\
\text { Format Publishing }\end{array}$ & $\begin{array}{c}\text { Month and Year of Transition } \\
\text { to Digital-only Format }\end{array}$ \\
\hline 1 & Journal of Tropical Pediatrics & 1.165 & 63 & January 2018 \\
\hline 2 & $\begin{array}{l}\text { Journal of the History of Medicine and } \\
\text { Allied Sciences }\end{array}$ & 2.088 & 74 & July 2020 \\
\hline 3 & ANZ Journal of Surgery & 1.872 & 90 & January 2022 \\
\hline 4 & Age and Ageing & 10.668 & 50 & January 2022 \\
\hline 5 & $\begin{array}{l}\text { Journal of Diagnostics and Treatment of } \\
\text { Oral and Maxillofacial Pathology }\end{array}$ & - & 5 & January 2022 \\
\hline
\end{tabular}

Wiley \& Sons, Inc, ${ }^{3}$ Elsevier, ${ }^{5}$ and other publishers ${ }^{5}$ to be "more agile" 3 and "to avoid becoming a fossil."

In sum, we hope you will enjoy the new chapter in the growth and evolution of our Journal in the form of a fully open access printable digital publication.

Most readers already access the journal's content online. ${ }^{3}$ -Julian A. Smith (2021)

Editor in Chief, ANZ Journal of Surgery

Today you have that gift of a free distribution [via internet]. ${ }^{8}$ -Jeff Bezos (2018)

Founder of Amazon at the Economic Club of Washington,

D.C. answering about buying Washington Post

\section{REFERENCES (8)}

1. Bassat Q. Goodbye paper: we are moving to online only publication. J Trop Pediatr 2017;63(6):417. https://doi.org/10.1093/tropej/fmx076

2. Hirshbein L. Editorial - news about the Journal of the History of Medicine and Allied Sciences. J Hist Med Allied Sci 2020;75(3):243-4. https://doi.org/10.1093/jhmas/jraa026
3. Smith JA, Malisano LP. ANZ Journal of Surgery: soon to make the shift from print to digital publishing. ANZ J Surg 2021;91(6):1051.

https://doi.org/10.1111/ans.16919

4. Harwood RH. Editor's view. Age Ageing 2021;50(6):1863-4.

https://doi.org/10.1093/ageing/afab202

5. Wymbs S. To print or not to print -4 things societies should consider before moving members online only [document on the internet]; 11 Nov 2020 [cited 25 Dec 2021]. Available from:

https://www.elsevier.com/connect/4-things-toweigh-before-moving-a-journal-from-print-toonline-only

6. Daily JW. Transition to online-only journals in 2019. J Aircr 2018;55(5):1761.

https://doi.org/10.2514/1.C035178

7. Goldsworthy S. The evolution of academic publishing in a digital age [document on the internet]; $06 \mathrm{Nov}$ 2021 [cited 26 Dec 2021]. Available from:

https://www.universityworldnews.com/post. php? story=20211101135742731

8. Jeff Bezos, CEO and Founder, Amazon [document on the internet]; 21 Sep 2018 [cited 26 Dec 2021]. Available from:

https://m.youtube.com/watch?v=zN1PyNwjHpc 